\section{PE D A G O A L}

Jurnal IImiah Pendidikan

http://journal.unpak.ac.id/index.php/pedagonal

\title{
KONTRIBUSI PENGETAHUAN TEKNOLOGI INFORMASI \& KOMUNIKASI TERHADAP KINERJA GURU
}

\author{
Wawan Syahiril Anwar ${ }^{1}$, Santa ${ }^{2}$ \\ ${ }^{1 \& 2}$ Program Studi Pendidikan Guru Sekolah Dasar Universitas Pakuan \\ wawansyahirilanwar@gmail.com
}

\begin{abstract}
ABSTRAK
Pemanfaatan teknologi informasi dan komunikasi telah digunakan secara luas untuk meningkatkan kinerja, dalam penelitian ini akan diungkap seberapa jauh kontribusi variabel pengetahuan teknologi informasi \& komunikasi terhadap variabel kinerja guru. Penelitian dilakukan terhadap guru IPA SMP se-Wilayah Kota Bogor. Hasil penelitian menunjukkan bahwa terdapat kontribusi yang signifikan pengetahuan teknologi informasi \& komunikasi (variable X) terhadap kinerja guru (variable Y). Besarnya kontribusi ditunjukkan oleh kekuatan kontribusi sebesar 38,6\% dengan persamaan regresi $\hat{Y}=113,602+1,934 X$. Perubahan setiap satu unit variabel pengetahuan guru tentang teknologi informasi \& komunikasi akan menyebabkan perubahan kenaikan kinerja guru sebesar 1,934 unit. Implikasi dari hasil penelitian ini dapat direkomendasikan bahwa untuk meningkatkan kinerja seorang tenaga pendidik dapat dilakukan melalui upaya peningkatan pengetahuannya tentang teknologi informasi \& komunikasi.
\end{abstract}

Kata Kunci: Teknologi Informasi \& Komunikasi, Kinerja

\begin{abstract}
Utilization of information and communication technology has been used widely to improve performance, in this research will be revealed how far the contribution of information technology knowledge \& communication variable to teacher performance variable. The research is conducted to science teachers of junior high school in Bogor City. The results showed that there was a significant contribution between knowledge of information \& communication technology (variable X) on teacher performance (variable $\mathrm{Y})$. The amount of contribution is shown by the contribution force of $38.6 \%$ with regression equation $\hat{\mathrm{Y}}=113,602+1,934 \mathrm{X}$. Changes in each unit of teacher knowledge variable about information \& communication technology will cause change of teacher performance increase equal to 1,934 unit. The implications from the results of this study are that it can be recommended to improve the performance of an educator, knowledge
\end{abstract}


about information \& communication technology must first be increased.

Keywords: Information \& Communication Technology, Performance

\section{PENDAHULUAN}

Ranah kognitif masyarakat modern menurut badan Perserikatan Bangsa Bangsa seperti diungkapkan oleh Unesco (2002:1) menyebutkan bahwa ranah kognitif masyarakat modern berkaitan dengan teknologi informasi dan komunikasi (TIK) telah menjadi salah satu fondasi pembangunan di segala bidang. Sebagian negara saat ini menganggap pemahaman tentang TIK dan penguasaan konsep-konsepnya merupakan bagian dari jantung pendidikan yang disejajarkan dengan kemampuan membaca, menulis dan berhitung. Kehadiran teknologi informasi dan komunikasi sebagai alat telah digunakan oleh individu maupun organisasi untuk membantu menyelesaikan tugas pekerjaan dengan lebih cepat dan akurat. Teknologi informasi dan komunikasi tersebut dipercaya dapat membantu berbagai jenis pekerjaan, arus informasi dan komunikasi menjadi lebih mudah sehingga menjadi pilihan bagi individu maupun organisasi untuk mendampingi aktivitas keseharian. Pemanfaatan teknologi informatika dan komunikasi dalam dunia pendidikan ditujukan supaya dapat meningkatkan kualitas tenaga pendidik serta meningkatkan kualitas pembelajaran.

Pesatnya perkembangan teknologi informasi dan komunikasi harus disikapi secara positif dan diimbangi dengan kehandalan sumber daya manusianya sehingga dapat meningkatkan kinerja dengan memanfaatkan teknologi ini untuk kemajuan pada setiap sektor termasuk dalam sektor pendidikan, khususnya dalam proses pembelajaran. Sejalan dengan hal tersebut pemerintah melalui Permendiknas nomor 16 tahun 2007 tentang standar kompetensi guru, menegaskan bahwa guru dituntut supaya memimiliki kompetensi untuk dapat memanfaatkan teknologi informasi dan komunikasi sesuai kepentingan pembelajaran dan pengembangan tenaga guru.

Kinerja guru sebagai suatu sistem pencerdasan anak bangsa, dalam prakteknya dewasa ini masih dihadapkan pada berbagai persoalan. Salah satu persoalan klasik dunia pendidikan Indonesia adalah menyangkut kualitas pendidikan yang masih belum menggembirakan, hal ini tentu tidak terlepas dari keberadaan lembaga pendidikan sebagai organisasi pendidikan formal yang merupakan ujung tombak perbaikan kualitas pendidikan, oleh karenanya upaya perbaikan mutu harus dimulai dari lembaga pendidikan terutama dalam hal sumber daya manusianya yaitu guru.

Menurut Behan \& Holmes seperti dikutip oleh Munir (2009:31) bahwa teknologi informasi dan komunikasi adalah segala bentuk teknologi yang terlibat untuk me-record, menyimpan, memproses, memancarkan, menghantarkan, memanipulasi dan menerima informasi. Peran kemajuan teknologi informasi dan komunikasi di 
Indonesia saat ini telah menjadi bagian dari gaya hidup masyarakat Indonesia terutama bagi mereka yang berada di wilayah perkotaan. Lembaga-lembaga pendidikan mulai dari tingkat sekolah dasar sampai perguruan tinggi telah mulai mengintegrasikan teknologi informasi komunikasi dalam kegiatan pembelajarannya.

Menurut Mohamad Surya (2006:6) menyebutkan bahwa pemanfaatan TIK dalam memperbaiki mutu pembelajaran memerlukan tiga hal yang harus diwujudkan yaitu, (1) siswa dan guru harus memiliki akses kepada teknologi digital dan internet dalam kelas, sekolah, dan lembaga pendidikan guru, (2) harus tersedia materi yang berkualitas, bermakna, dan dukungan kultural bagi siswa dan guru, dan (3) guru harus memiliki pengetahuan dan ketrampilan dalam menggunakan alat-alat dan sumber-sumber digital untuk membantu siswa agar mencapai standar akademik. Implementasi pemanfaatan TIK oleh guru menurut Munir (2009:42) bahwa pengintegrasikan teknologi informasi dan komunikasi ke dalam pembelajaran dimaksudkan untuk meningkatkan kompetensi pengajar dalam usahanya meningkatkan mutu proses pembelajaran. Teknologi informasi dan komunikasi memberikan kemudahan dan bersifat inovatif sehingga proses pembelajaran dapat berlangsung lebih efektif dan efisien. Dalam pembelajaran dengan TIK, memungkinkan siswa berinteraktif dengan fakta, data dan informasi yang lebih baik daripada pembelajaran konvensional.

Jenis media pembelajaran TIK yang relatif terjangkau biaya serta mudah menggunakannya, antara lain: Multimedia presentasi, computer based training dengan $\mathrm{CD}$ interaktif, internet dan fitur-fiturnya, dan online learning untuk pembelajaran interaktif. Multimedia presentasi digunakan untuk menjelaskan materi-materi yang sifatnya teoritis, digunakan dalam pembelajaran klasikal dengan group belajar yang banyak peserta didiknya. Alat ini terdiri dari multimedia computer yang digabungkan dengan projector. Menurut Fidiatno untuk mengolah materi presentasi dapat menggunakan software aplikasi misalnya power point dari Microsoft. Media pembelajaran cukup efektif sebab memiliki keunggulan dapat menggabungkan audio visual dengan tambahan animasi yang menarik. Media bentuk lain yang dapat menyajikan bahan presentasi sebagai alternative menggunakan over head projector (OHP) dengan terlebih dahulu bahan presentasi ditulis pada lembaran plastik transparansi. Alat lainnya yang dapat digunakan yaitu film slides projector, alat ini butuh persiapan yang cukup lama karena terlebih dahulu harus membuat positif film. Kedua jenis media proyeksi ini masih kalah menarik dibandingkan multimedia computer plus projector, sedangkan media Computer based training dengan $\mathrm{CD}$ interaktif merupakan sebuah media yang dikemas dalam sebuah CD (Compact Disk) dengan program aplikasi interaktif di dalamnya. Compact Disc pada CD Interaktif yang diprogram dengan baik akan mampu mengarahkan dan memotivasi pembelajar sesuai dengan kemampuannya.

Menurut Wibowo (2008:4) bahwa kinerja merupakan implementasi dari rencana kerja yang telah disusun. Implementasi kinerja dilakukan oleh sumber daya manusia yang memiliki kemampuan, kompetensi, motivasi, dan kepentingan. Menurut Wibowo kinerja dapat dipandang sebagai proses maupun hasil pekerjaan. Kinerja merupakan 
suatu proses tentang bagaimana pekerjaan berlangsung dan merupakan tampilan nyata di dunia kerja yang berbasis pada kompetensi, yaitu berupa penguasaan dasar untuk tampil secara nyata pada tempat unit-unit layanan tertentu. Sedangkan kompetensi merupakan sebuah prakondisi, berupa seperangkat pengetahuan dasar teoritis, keterampilan, nilai-nilai dasar yang direfleksikan dalam kebiasaan berfikir dan bertindak yang diterapkan di dalam dunia kerja sesuai dengan standar kinerja yang dibutuhkan, dengan demikian kinerja merupakan bagian integral dari sejumlah kompetensi.

Selanjutnya Hersey dan Johnson dalam Wibowo (2008:351) menyatakan bahwa kinerja dipengaruhi oleh kemampuan dalam hal pengetahuan dan keterampilan, kejelasan memahami peran yang diberikan organisasi, dukungan dari organisasi, insentif yang diperoleh apakah sesuai dengan harapannya, keabsahan kedudukannya dalam organisasi, dan lingkungan kerja yang cocok. Penilaian kinerja merupakan alat yang berfaedah tidak hanya untuk mengevaluasi kerja pegawai tetapi juga untuk mengembangkan dan memotivasi para pegawai. Penilaian kinerja berlangsung pada periode waktu tertentu dengan standar penilaian yang berlandaskan persyaratan kerja serta kompetensi tertentu. Penilaian kinerja harus mengacu pada kadar pencapaian tugas-tugas yang merefleksikan seberapa baik pegawai memenuhi persyaratan sebuah pekerjaannya.

Penilaian terhadap kinerja guru terdapat dua aspek kemampuan guru yakni: 1) Kemampuan membuat rencana pelajaran yang terdiri atas; merencanakan pengorganisasian bahan pembelajaran, merencanakan pengelolaan kegiatan belajar mengajar, merencanakan pengelolaan kelas, merencanakan penggunaan media dan sumber pembelajaran, merencanakan penilaian prestasi siswa untuk kepentingan pembelajaran, dan 2) Kemampuan dalam praktik mengajar, terdiri atas; penggunaan metode, media, dan bahan latihan sesuai dengan tujuan mengajar, berkomunikasi dengan siswa, mendemonstrasikan khazanah metode mengajar, mendorong dan menggalakan keterlibatan siswa dalam pembelajaran, mendemonstrasikan penguasaan mata pelajaran dan relevansinya, mengorganisasi waktu, ruang, bahan, dan perlengkapan pembelajaran, serta melaksanakan evaluasi pencapaian siswa dalam proses pembelajaran.

Berdasarkan latar belakang pemikiran bahwa pengetahuan teknologi informasi \& komunikasi diperlukan untuk peningkatan kualitas kinerja, maka penulis melakukan penelitian yang akan mengungkap permasalahan, yaitu: Adakah kontribusi pengetahuan guru tentang teknologi informasi \& komunikasi terhadap kinerjanya? Adapun tujuan penelitian ini adalah untuk mengetahui seberapa besar kontribusi pengetahuan guru tentang teknologi informasi \& komunikasi terhadap kinerjanya. Informasi ini diharapkan dapat dijadikan acuan untuk meningkatkan kinerja tenaga pendidik dilihat dari aspek pengetahuan tentang teknologi informasi \& komunikasi.

\section{METODOLOGI PENELITIAN}

Metode penelitian yang digunakan dalam penelitian ini adalah deskriptif kuantitatif, dengan tujuan untuk mengungkap kontribusi variabel pengetahuan guru tentang teknologi informasi dan komunikasi (X) terhadap variabel kinerja guru (Y).

Data dikumpulkan pada rentang 
waktu Agustus 2017 sampai September 2017, alat pengumpul data berupa instrumen angket dan instrumen tes. Populasi sasaran dalam penyebaran angket pada responden adalah guru-guru yang mengajar Ilmu Pengetahuan Alam (IPA) SMP Negeri di Wilayah Kota Bogor berjumlah 101 orang guru dengan sampel secara random proporsional. Jumlah sampel dalam penelitian ini dilakukan menggunakan teknik simple random sampling dengan rumus Slovin :

$$
n=\frac{N}{1+N . e^{2}} \quad(\text { Siregar, 2014: 61) }
$$

Keterangan:

$\mathrm{n}=$ Jumlah Sampel

$\mathrm{N}=$ Jumlah Populasi $\mathrm{e}=$ Presisi yang ditetapkan $(10 \%=0,1)$

$$
=\frac{101}{1+101(0,1)^{2}}=\frac{101}{2,01}=50,24 \text { Jumlah }
$$

sampel dibulatkan menjadi 50

responden

Pengukuran variable pengetahuan guru tentang teknologi informasi (X) komunikasi adalah melalui skor hasil tes 40 butir soal multiple choice yang diperoleh setelah responden menjawab instrumen tes pengetahuan Teknologi Informasi dan Komunikasi (TIK) sesuai indikator dengan kisi-kisi instrument tes sebagai berikut;

\begin{tabular}{|c|c|c|c|c|c|}
\hline \multirow[b]{2}{*}{ No. } & \multirow{2}{*}{ Materi Pengetahuan TIK } & \multicolumn{3}{|c|}{ Aspek Kognitif } & \multirow{2}{*}{$\begin{array}{c}\text { Jumlah } \\
\text { Butir }\end{array}$} \\
\hline & & $\mathrm{C}_{1}$ & $\mathrm{C}_{2}$ & $\mathrm{C}_{3}$ & \\
\hline 1. & dasar-dasar komputer & 1,2 & $5,6,7,8$ & 3,4 & 8 \\
\hline 2. & $\begin{array}{l}\text { teknologi multimedia } \\
\text { pembe-lajaran }\end{array}$ & 9,10 & $11,13,15$ & 12,14 & 7 \\
\hline 3. & program aplikasi power & 16 & 17,18 & 19, 20,21, & 7 \\
\hline 4. & $\begin{array}{l}\text { Computer Based Training } \\
\text { dengan CD Interaktif }\end{array}$ & 25 & 23,24 & 26 & 4 \\
\hline 5. & internet dan fitur-fiturnya & 27,28, 29, & $31,32,33$ & 34,35 & 9 \\
\hline 6. & online learning & 38,42 & 39 & 40,41 & 5 \\
\hline & Jumlah & 12 & 15 & 13 & 40 \\
\hline
\end{tabular}

Tabel 1. Kisi-kisi Instrumen Variable X

\section{Keterangan:}

$\mathrm{C}_{1}=$ Ingatan (recall)

$\mathrm{C}_{2}=$ Pemahaman (comprehension)

$\mathrm{C}_{3}=$ Penerapan (application)

Pengukuran variabel kinerja guru (Y) merupakan skor yang diperoleh guru melalui instrument angket 40 butir pertanyaan dengan skala Likert 1-5, penilaian kepala sekolah terhadap guru ybs. dengan instrumen berisi tentang penilaian terhadap faktor- faktor yang menjadi kunci keberhasilan guru dalam melaksanakan tugasnya di sekolah, melalui indikator kinerja guru dengan kisi-kisi instrument seperti tabel sebagai berikut: 
Tabel 2 Kisi-kisi Instrumen Variabel Y

\begin{tabular}{|c|c|c|c|c|}
\hline \multirow{2}{*}{ No. } & \multirow{2}{*}{ Indikator-Indikator } & \multicolumn{2}{|c|}{ Nomor Butir } & \multirow[t]{2}{*}{ Jumlah } \\
\hline & & Positif & Negatif & \\
\hline 1. & $\begin{array}{l}\text { perencanaan } \\
\text { pembe-lajaran }\end{array}$ & $1,2,3,4$ & 5 & 5 \\
\hline 2. & proses pembelajaran & $\begin{array}{c}6,7,8,9,10,11 \\
12,14,15,16\end{array}$ & 13,17 & 12 \\
\hline 3. & $\begin{array}{l}\text { pelaksanaan } \\
\text { pembe-lajaran }\end{array}$ & $18,20,21,23,24,25,26$ & 19,22 & 9 \\
\hline 4. & pelaksanaan remedial & 27,28 & 29 & 3 \\
\hline 5. & administrasi guru & $30,32,33,34,35$ & 31 & 6 \\
\hline 6. & pengembangan profesi & $36,37,39,40$ & 38 & 5 \\
\hline & Jumlah & 32 & 8 & 40 \\
\hline
\end{tabular}

Pengolahan data menggunakan metoda kuantitatif deskriptif dengan teknik analisis regresi yang berguna untuk mengukur kadar kontribusi antar variabel yang diteliti dengan menguji hipotesis yang telah diajukan. Sebelum dilakukan analisis regresi terlebih dahulu dilakukan Uji prasyarat normalitas dan homogenitas, selanjutnya dilakukan perhitungan analisis data dengan uji korelasi regresi dibantu dengan software program SPSS (Statistical Product and Service Solution).

Temuan Penelitian Dan Pembahasan Hasil pengukuran variabel kinerja guru (variable Y) berdasarkan perolehan skor angket penilaian kepala sekolah terhadap responden tercantum pada diagram histogram berikut ini: 


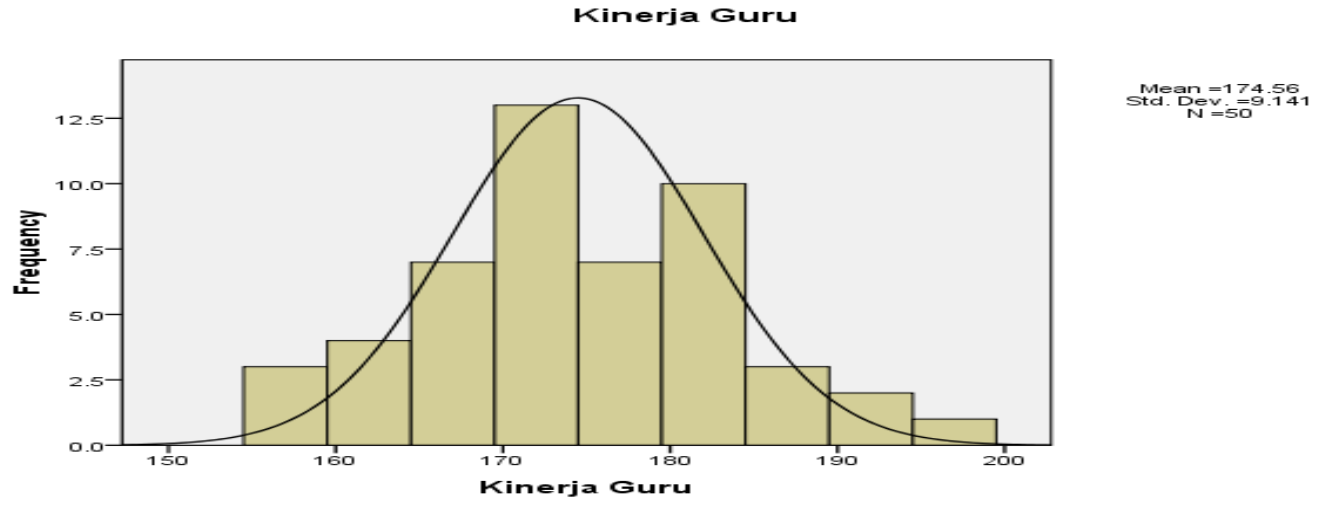

Gambar 1. Histogram Variabel Y

Untuk instrument 40 butir pertanyaan, skor teoritik terendah 40 , skor teoritik tertinggi 200, dan rata-rata skor teoritik 120. Perolehan data variable $Y$ memiliki skor empirik terendah 157 dan skor tertinggi 195, rata-rata skor (mean) sebesar 175.22, nilai tengah (median) sebesar 175, skor paling sering muncul (modus) 173,67.

Hasil pengukuran variabel pengetahuan teknologi informasi \& komunikasi, didapatkan data distribusi skor variable $\mathrm{X}$ seperti pada diagram histogram sebagai berikut:

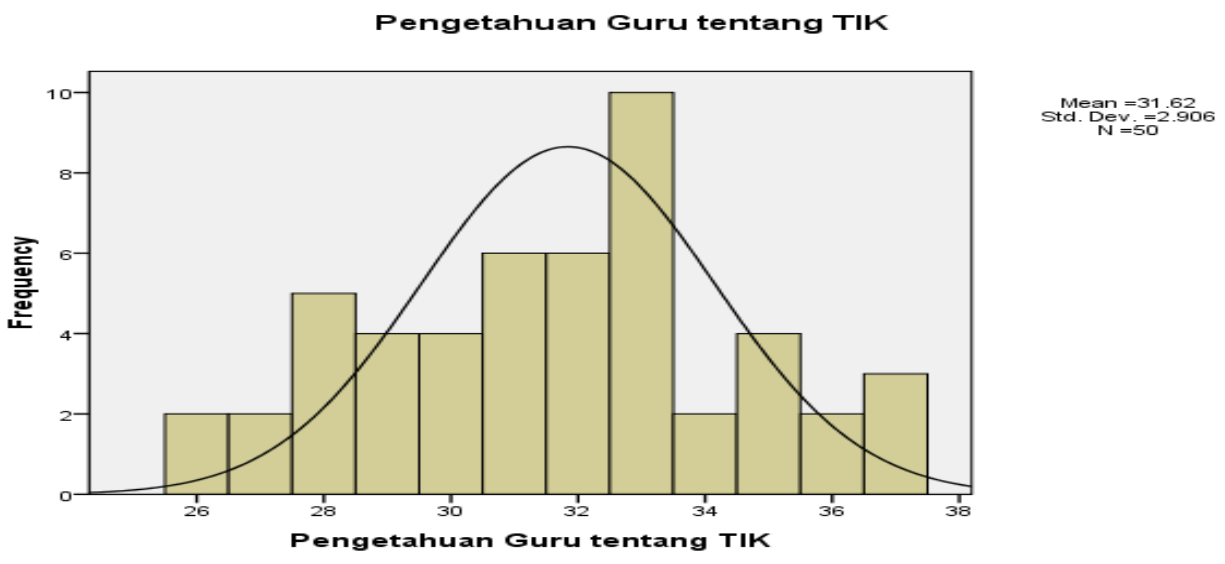

Gambar 2. Histogram Variabel X

Skor teoritis untuk 40 butir instrumen adalah antara 0 sampai dengan 40 dengan rata-rata skor teoritis 20. Data variable $\mathrm{X}$ memiliki skor tertinggi 37 dan skor terendah 26, rata-rata skor (mean) empirik sebesar 31,70 dengan nilai tengah (median) sebesar 32,33 dan modus 33. Rekapitulasi data penelitian dari variabel yang diteliti pada table berikut ini:

Tabel 3

Ringkasan Statistik Deskriptif Variabel Penelitian

\begin{tabular}{|c|c|c|c|c|c|c|}
\hline Variabel Penelitian & N & $\begin{array}{c}\text { Skor } \\
\text { Ideal }\end{array}$ & $\begin{array}{c}\text { Skor } \\
\text { Min }\end{array}$ & $\begin{array}{c}\text { Skor } \\
\text { Maks }\end{array}$ & $\begin{array}{c}\text { Rata- } \\
\text { rata }\end{array}$ & $\begin{array}{c}\text { Rata-rata } \\
\text { Empirik }\end{array}$ \\
\hline
\end{tabular}




\begin{tabular}{|l|c|c|c|c|c|c|}
\hline & & & & & Teoritik & \\
\hline Kinerja Guru (Y) & 50 & 200 & 157 & 195 & 120 & 175.22 \\
\hline $\begin{array}{l}\text { Pengetahuan Guru } \\
\text { tentang TIK (X) }\end{array}$ & 50 & 40 & 26 & 37 & 20 & 31.70 \\
\hline
\end{tabular}

Dari paparan data tersebut dapat dianalisis sebagai berikut:

Pertama, rata-rata skor pengetahuan guru tentang teknologi informasi \& komunikasi lebih besar dari rata-rata skor teoritiknya, hal ini menunjukkan bahwa para guru telah memiliki pengetahuan teknologi informasi dan komunikasi yang memadai untuk meningkatkan kinerjanya.

Kedua, rata-rata skor kinerja guru yang diteliti lebih besar dari rata-rata skor teoritik, hal ini menunjukkan bahwa para guru memiliki kinerja baik, mereka telah bekerja dengan baik sesuai dengan tuntutan pekerjaan sebagai tenaga pendidik.

Uji hipotesis untuk mengungkap kontribusi variable $X$ terhadap variable $Y$ dilakukan dengan bantuan program SPSS sehingga diperoleh hubungan fungsional antara variabel $\mathrm{X}$ dan $\mathrm{Y}$, seperti pada table berikut:

Tabel 4 Analisis Regresi Linier

Coefficients $^{\mathrm{a}}$

\begin{tabular}{|c|c|c|c|c|c|c|c|}
\hline \multirow{2}{*}{\multicolumn{3}{|c|}{ Model }} & \multicolumn{2}{|c|}{$\begin{array}{c}\text { Unstandardized } \\
\text { Coefficients }\end{array}$} & $\begin{array}{c}\text { Standardized } \\
\text { Coefficients }\end{array}$ & \multirow[b]{2}{*}{$\mathrm{t}$} & \multirow[b]{2}{*}{ Sig. } \\
\hline & & & B & Std. Error & Beta & & \\
\hline \multirow[t]{2}{*}{1} & (Constant) & & 113.602 & 11.183 & & 10.158 & .000 \\
\hline & $\begin{array}{l}\text { Pengetahuan } \\
\text { tentang TIK }\end{array}$ & Guru & 1.934 & .352 & .621 & 5.493 & .000 \\
\hline
\end{tabular}

a. Dependent Variable: Kinerja Guru

Tabel analisis regresi linier tersebut digunakan untuk Uji hipotesis, dapat ditunjukkan bahwa terdapat kontribusi positif antara pengetahuan guru tentang TIK (X) terhadap kinerja guru (Y) dengan persamaan regresi sebagai berikut: $\hat{Y}=$ $113,602+1,934$ X. Untuk menentukan keberartian persamaan regresi dapat diamati pada harga signifikansi $\mathrm{p}=0,00$ sedangkan harga $\alpha=0,05$ dengan demikian $\mathrm{p}<\alpha$ berarti hipotesis $\mathrm{H}_{\mathrm{o}}$ ditolak atau hipotesis $\mathrm{H}_{1}$ diterima. Hasil uji tersebut menunjukkan bahwa model persamaan regresinya signifikan dan dapat dipergunakan untuk menganalisis hubungan antara $\mathrm{Y}$ dan $X$. Dengan demikian dapat disimpulkan bahwa hipotesis $\mathrm{H}_{1}$ yang menyatakan terdapat kontribusi antara pengetahuan guru tentang TIK terhadap kinerja guru dapat diterima. Untuk menguji kelinearan regresi digunakan uji linearitas dengan bantuan program SPSS. Hasil uji linearitas didapat signifikansi $\mathrm{p}=0.00<\alpha$ berarti hubungan $\mathrm{X}$ dan $\mathrm{Y}$ adalah linear dengan persamaan $\hat{Y}=$ 
$113,602+1,934 \mathrm{X}$ dapat digambarkan

Gambar 3 berikut:

dalam model hubungan seperti pada

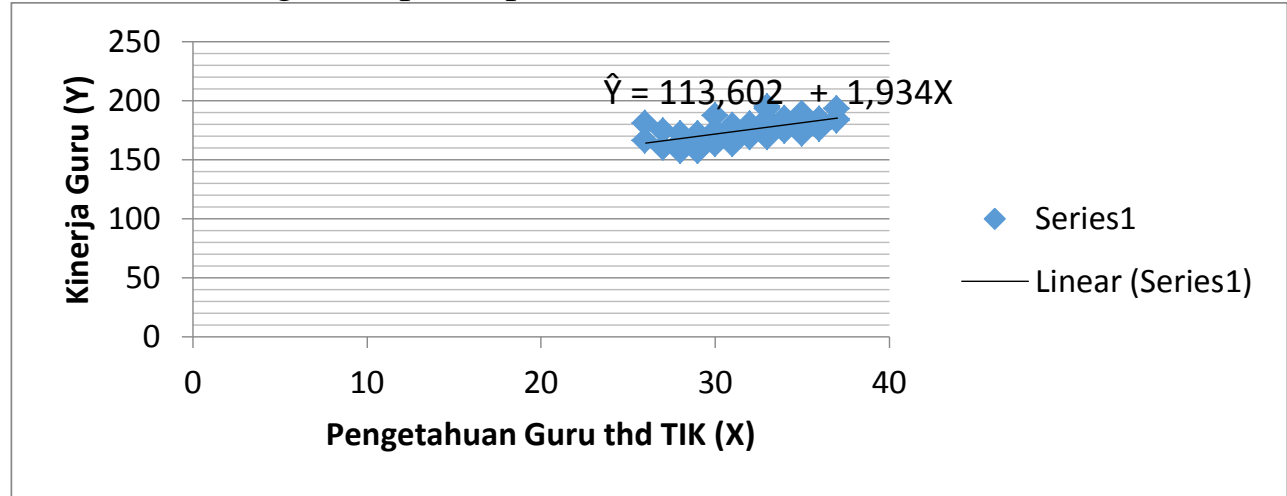

Gambar 3. Model hubungan antara varibel Y dengan X

Kekuatan hubungan antara variabel pengetahuan guru tentang TIK (X) dengan kinerja guru (Y) ditunjukkan oleh koefisien korelasi $\mathrm{r}_{\mathrm{y}}=$ 0,621. Besarnya kontribusi ditunjukkan oleh nilai koefisien determinasi $\mathrm{X}$ terhadap $\mathrm{Y}$ adalah $\left(\mathrm{r}_{\mathrm{y}}\right)^{2}=$ 0,386 artinya $38,6 \%$ varians skor kinerja guru dapat dijelaskan oleh variabel pengetahuan guru tentang teknologi informasi \& komunikasi. Hasil tersebut menunjukkan bahwa penggunaan teknologi informasi dan komunikasi memberikan kontribusi $38,6 \%$ terhadap kinerja guru. Bentuk persamaan regresi tersebut dapat diartikan bahwa setiap penambahan satu unit variabel pengetahuan guru tentang TIK akan menyebabkan kenaikan kinerja guru sebesar 1,934 unit Hal ini berarti bahwa pengetahuan guru tentang teknologi informasi \& komunikasi merupakan salah satu factor penting untuk meningkatkan kinerja personal guru. Hal ini sejalan dengan pendapat Munir (2009:42) bahwa bila guru memiliki pengetahuan dan mengintegrasikan teknologi informasi dan komunikasi ke dalam pembelajaran, maka ia akan dapat meningkatkan kompetensinya dalam mengelola pembelajaran sekaligus meningkatkan kinerjanya. Teknologi informasi dan komunikasi memberikan kemudahan dan bersifat inovatif sehingga proses pembelajaran dapat berlangsung lebih efektif dan efisien. Hal ini dimungkinkan karena dengan TIK siswa dapat berinteraktif dengan fakta, data dan informasi yang lebih baik daripada pembelajaran konvensional.

Hasil penelitian relevan yang dilakukan oleh Caty-Ann Rampersad (2012) menunjukkan bahwa pengetahuan guru yang memadai tentang teknologi informasi dan komunikasi dapat membantu guru dalam menjalankan tugas pokoknya di sekolah. Dengan memanfaatkan TIK sebagai media dan sumber belajar serta sebagai alat bantu menyelesaikan administrasi pembelajaran maka pekerjaan guru dalam merencanakan, melaksanakan dan mengevaluasi pembelajaran menjadi lebih efektif dan efisien untuk mencapai tujuan pembelajaran di sekolah.

Pengetahuan TIK dapat dimanfaatkan secara terintegrasi dalam mengelola tugas seorang guru, sehingga meningkatkan efisiensi pengelolaan kegiatan pembelajaran, mendorong peserta didik untuk belajar lebih mandiri, 
memudahkan guru menyajikan berbagai jenis materi pelajaran yang sulit, dan membantu mempermudah peserta didik mempelajari materi pelajaran. Dengan demikian akan meningkatkan kinerja individu guru. Dengan kata lain bahwa semakin baik pengetahuan guru tentang Teknologi Informasi \& Komunikasi maka akan makin baik kinerja guru.

\section{Kesimpulan}

Terdapat kontribusi positif yang signifikan dari pengetahuan guru tentang teknologi informasi \& komunikasi terhadap kinerja guru, dengan kekuatan kontribusi sebesar $38,6 \%$ menentukan kinerja guru. Kenaikan kinerja guru mengikuti persamaan regresi $\hat{Y}=113,602+1,934$ $X$. Perubahan setiap satu unit variabel pengetahuan guru tentang teknologi informasi \& komunikasi (X) akan menyebabkan perubahan kenaikan kinerja guru (Y) sebesar 1,934 unit. Apabila guru memiliki pengetahuan dan memanfaatkan teknologi informasi \& komunikasi ke dalam tugas pekerjaannya, maka ia akan dapat meningkatkan kompetensinya dalam mengelola tugas pekerjaannya sehingga dapat meningkatkan kinerjanya, oleh karena itu perlu upaya meningkatkan pengetahuan guru tentang teknologi informasi \& komunikasi dalam rangka memberi kontribusi terhadap peningkatan kinerja guru.

\section{Daftar Pustaka}

Ade Koesnandar, Teknologi Informasi \& Komunikasi (TIK) Untuk Pembelajaran, Jakarta: Pusat Teknologi Informasi dan Komunikasi Pendidikan Departemen Pendidikan Nasional, 2008.
Aji Supriyanto, Pengantar Teknologi Informasi, Jakarta: Salemba Infotek, Cetakan ke 2, 2007.

Angkowo dan Kosasih, Optimalisasi Media Pembelajaran, Jakarta: PT Grasindo, 2007.

Bloom, S. Benyamin, Taxonomy of Educational Objectives: Book 1 Cognitive Domain, New York: Longman Inc, 1965.

Caty-Ann Rampersad, Teachers' Perceptions of The Contribution of Information And Communication Technology To The Teaching of Modern Studies, Using An Integrated System, In An Urban Secondary School, 2011,

(

https://www.researchgate.net/pub lication/277743351 )

Depdiknas, Penilaian Kinerja Guru, Jakarta: Direktorat Tenaga Kependidikan, Direktorat Jenderal Peningkatan Mutu Pendidik dan Tenaga Kependidikan - Departemen Pendidikan Nasional, 2008.

Hamzah B. Uno, Profesi Kependidikan. Jakarta: PT Bumi Aksara, 2007.

Mohamad Surya, "Potensi Teknologi Informasi Dan Komunikasi Dalam Peningkatan Mutu Pembelajaran Di Kelas", Makalah Seminar Nasional, Pustekkom Depdiknas, 2006.

Munir, Pembelajaran Jarak Jauh Berbasis Teknologi Informasi dan Komunikasi, Bandung: 
Alfabeta, 2009.

Sallis, Edward, Total Quality Management In Education. Alih Bahasa Ahmad Ali Riyadi. Cetakan VIII. Jakarta: IRCiSoD, 2008.

Siregar Syofian, Statistik Parametrik, Jakarta, Bumi Aksara, 2014.

SPSS Untuk Pengolahan Data Statistik,
Yogyakarta: Penerbit Andi \& Wahana Komputer, 2009.

Sudarwan Danim, Kinerja Staf dan Organisasi, Bandung: Pustaka Setia, 2008.

Sudirman Siahaan, Pemanfaatan Teknologi Informasi (TIK) Dalam Pembelajaran, Jakarta: Pustekom Depdiknas, 2009. 